\title{
A LESSON LEARNED FROM MYRIAD: THE AFFORDABLE CARE ACT AS BOTH AN INCENTIVE AND AN ALTERNATIVE for Invalidating Stem Cell Patents
}

\author{
MARYN WILCOXSON*
}

INTRODUCTION

The patentability of human genes and stem cells has been heavily debated in the last decade by members of both the scientific and legal communities. While " $[t]$ he fundamental policy of the patent system is to encourage the creation and disclosure of new, useful, and nonobvious advances in technology and design by granting the inventor the reward of exclusive right to practice the invention for a period of years," this reward of innovation is not without risk. ${ }^{1}$ The patent system must be cautious of the legal monopoly patents provide, which has the potential to bring competition and further innovation to a halt. This balancing act is especially important in biological patenting, where patents have the potential to hinder the research, accessibility, and affordability of diagnostic tests and medical treatments.

On June 13, 2013, the United States Supreme Court, in Association for Molecular Pathology v. Myriad Genetics, Inc., issued a unanimous landmark decision that held that patents on human genes are invalid because "a naturally occurring DNA segment is a product of nature and not patent eligible merely because it has been isolated." 2 This holding invalidated Myriad Genetics' patents on the BRCA1 and BRCA2 genes, which are linked to an increased risk of breast and ovarian cancers. ${ }^{3}$ In the weeks following the decision, other biotech companies began offering genetic testing for these genes, and the costs to patients for the preventive tests were significantly lowered. ${ }^{4}$ The lower costs of these tests is particularly important considering recent American healthcare reform under the Patient Protection and Affordable Care Act ("ACA"), which places an emphasis on affordable and accessible preventative care. ${ }^{5}$

While the Myriad decision made human genes ineligible for patents because they are a product of nature, the United States Supreme Court did not extend the holding of Myriad to the patenting of other isolated human biological materials, such as stem cells. ${ }^{6}$ Because the Myriad decision did not close the door on the

* J.D. Candidate, 2015, Indiana University Robert H. McKinney School of Law; Bachelor of Arts in Biology and Criminal Justice, 2011, Indiana University, Bloomington, Indiana.

1. 60 AM. JUR. 2D Patents $\S 2$ (2013); In re CFLC, Inc., 89 F.3d 673 (9th Cir. 1996).

2. Ass'n for Molecular Pathology v. Myriad Genetics, Inc., 133 S. Ct. 2107, 2111 (2013).

3. Id. at 2119 .

4. Jaimy Lee, Quest Diagnostics to Offer Genetic Tests for Breast Cancer Risk, MODERN HEALTHCARE (Oct. 16, 2013), http://www.modernhealthcare.com/article/20131016/NEWS/ 310169965, archived at http://perma.cc/M5L9-CGAQ.

5. Patient Protection and Affordable Care Act, Pub. L. No. 111-148, Title IV, 124 Stat. 119, 124-28 (2010).

6. See Ass'n for Molecular Pathology, 133 S. Ct. 2107.

http://dx.doi.org/10.18060/4806.0010 
possibility of stem cell patents being invalidated, the nonprofit group, Consumer Watchdog ("Watchdog"), has brought an appeal in the Federal Circuit challenging the patents on human embryonic stem cells ("hES cells") held by the Wisconsin Alumni Research Foundation ("WARF"). " Watchdog argues that under Myriad, these stem cells are products of nature and therefore are not patentable solely because they have been isolated. ${ }^{8}$

As the United States undergoes substantial health care reform and places an emphasis on affordable and preventive care, stem cell treatment therapies have the potential to provide a cost effective alternative to expensive lifelong treatments for chronic conditions. The purpose of this Note is to advocate that in light of Myriad, the invalidation of embryonic stem cell patents is necessary in order to further stem cell research and develop cost-saving treatments for chronic conditions. Part I of this Note provides a case study on Myriad by reviewing the science and reasoning behind the decision and explains how the invalidation of gene patents has altered the genetic testing landscape and helped to meet key provisions of the ACA. Part II provides a background on the science and current patenting landscape of stem cells. Part II also explains how stem cells are similar to genes and why they should be invalidated in light of Myriad. Part III analyzes what the United States stands to gain under the ACA from the invalidation of stem cell patents, including lowered costs for treatment of chronic conditions. Finally, Part IV proposes that Congress extend the Qualifying Therapeutic Discovery Project of the ACA as an alternative to stem cell patenting.

\section{The Myriad Decision, Genetic Testing, AND The AfFordable CARE ACT: A CASE STUDY}

The 1990s were a decade of rapid discovery and development in the genetics research and biotechnology fields. ${ }^{9}$ In the midst of the Human Genome Project, large amounts of public and private funds were being invested in gene discovery and sequencing. ${ }^{10}$ All of this research was being conducted in the wake of the United States Supreme Court case, Diamond v. Chakrabarty, ${ }^{I I}$ which allowed for the widespread patenting of biological organisms and genes. ${ }^{12}$ At the American Society of Human Genetics Meeting in 1990, Doctor Mary-Claire King

7. Brief for Appellant at 14, Consumer Watchdog v. Wis. Alumni Research Found., 753 F.3d 1258 (Fed. Cir. 2014) (No. 2013-1377).

8. Id.

9. Bryn Williams-Jones, History of a Gene Patent: Tracing the Development and Application of Commercial BRCA Testing, 10 HeALTH L.J. 123, 124 (2002).

10. Id. (noting that United States public expenditures on the Human Genome Project totaled more than $\$ 3$ billion).

11. Diamond v. Chakrabarty, 447 U.S. 303, 309 (1980) (holding that plaintiff's genetically engineered bacterium was patentable because it was not naturally occurring and was "a product of human ingenuity").

12. Williams-Jones, supra note 9, at 125. 
announced that a gene associated with an increased risk in breast cancer, BRCA1, had been isolated. ${ }^{13}$

In 1994, researchers at Utah-based biopharmaceutical and genomics company, Myriad Genetics, sequenced BRCA1 and "filed for U.S 'composition of matter' and 'methods-of-use' patents on the whole gene, as well as for a variety of deleterious mutations." 14 A year later, Myriad filed for a United States patent on the BRCA2 gene. ${ }^{15}$ During the race to patent the various BRCA genes, the United States Patent and Trademark Office granted conflicting patents to various biotech companies in addition to the patents held by Myriad. ${ }^{16}$ Myriad settled with the other companies and purchased all outstanding patents on the BRCA genes. ${ }^{17}$

\section{A. A Background on the Science: BRCA1 and BRCA2 Genetic Testing}

After the completion of the Human Genome Project and the isolation of the BRCA1 and BRCA2 genes, Myriad's patents on the genes afforded the company with the sole right to develop and market a test to detect the presence of a BRCA mutation in women. ${ }^{18}$ It took Myriad nearly two years' worth of research to develop a method of testing for the mutation and another three years of clinical trials before the test could be marketed to patients. ${ }^{19}$

1. The Science Behind the BRCA Genes.-The BRCA1 and BRCA2 genes are human genes that produce tumor suppressor proteins and repair damaged DNA. ${ }^{20}$ When these genes become mutated, they cannot carry out their designated repair functions. ${ }^{21}$ Without repair, damaged cells become more likely to develop additional genetic alterations that can lead to cancer. ${ }^{22}$ In the case of the BRCA genes, these inherited mutations lead to an increased risk of breast and

13. Id. at 131 .

14. Id.

15. Id. at 132 .

16. Id.

17. Id. at 132-33; see also Two Foes Settle War Over Owning Breast Cancer Gene, THE ROYAL SOCIETY OF NEW ZEALAND (May 19, 1998), http://www.royalsociety.org.nz/1998/05/19/ two-foes-settle-war-over-owning-breast-cancer-gene/, archived at http://perma.cc/QD5EEATV(discussing that the Myriad settlement with Oncormed was for an undisclosed amount but under the terms of the agreement Oncormed agreed to stop offering BRCA testing services and would refer all potential clients to Myriad).

18. J.J. Colao, How A Breast Cancer Pioneer Finally Turned a Profit, FonBES (Oct. 17, 2012), http://www.forbes.com/sites/jjcolao/2012/10/17/how-a-breast-cancer-pioneer-finally-turneda-profit/, archived at http://perma.cc/CB6C-5QGZ.

19. Id.

20. BRCA1 and BRCA2: Cancer Risk and Genetic Testing, NAT'L CANCER InST. (Aug. 5, 2013), http://www.cancer.gov/cancertopics/factsheet/Risk/BRCA, archived at http://perma. cc/2SHP-5Z35.

21. Id.

22. Id. 
ovarian cancers in women. ${ }^{23}$ The harmful mutation can be inherited from either the mother or the father, which means that a child who has a parent that is a carrier of the BRCA mutation has a fifty percent chance of inheriting the mutated gene. $^{24}$

The risk of breast and ovarian cancer in women who have a mutation in either one of the BRCA genes is significant. ${ }^{25}$ BRCA mutations account for approximately twenty to twenty-five percent of hereditary breast cancer, five to ten percent of breast cancers overall, and approximately fifteen percent of all ovarian cancers. ${ }^{26}$

2. Myriad's BRCA Test.-Fortunately, for women who do suffer from an inherited BRCA gene, the research done over the last two decades has resulted in genetic testing that indicates the presence of a BRCA mutation. ${ }^{27}$ This test allows women to make preventive treatment decisions in light of their potential increased risks for these cancers. ${ }^{28}$ Because Myriad patented all forms and mutations of the BRCA genes, Myriad reigned as the "exclusive provider for genetic testing for hereditary breast [and ovarian] cancer." ${ }^{29}$ Myriad developed and marketed its unique BRCA screening test known as BRACAnalysis. ${ }^{30}$ This test has the ability to detect the presence of a deleterious, potential cancer-causing mutation in the BRCA1 and BRCA2 genes by analyzing a patient's blood or saliva. ${ }^{31}$

\section{B. The Genetic Testing Landscape Prior to the Myriad Decision}

1. Myriad's Monopoly and Insurance Coverage.-Prior to the Myriad decision, Myriad Genetics held a monopoly on genetic testing for the BRCA1 and BRCA2 genes. ${ }^{32}$ Myriad's patent on both the gene and the gene mutations meant that other companies were not able to develop and market alternative BRCA testing methods to patients. ${ }^{33}$ This monopoly led to high cost tests for patients

23. $I d$.

24. Id.

25. Id.

26. $I d$.

27. BRACAnalysis: Hereditary Cancer Testing for Hereditary Breast and Ovarian Cancer, MYRIAD, http://www.myriad.com/products/bracanalysis/ (last visited Oct. 8, 2013), archived at http://perma.cc/6KCH-Y7TR.

28. Id.

29. Williams-Jones, supra note 9, at 133 (inferring that BRACAnalysis was first marketed in 1996 and was the primary test on the market until the Myriad decision was issued in the summer of 2013).

30. BRACAnalysis, supra note 27.

31. $I d$.

32. John Laueman, DNA Tests Fail to Win Insurer Consent with Lives at Stake, BLOOMBERG (June 29, 2012, 5:37 PM), http://www.bloomberg.com/news/2012-06-29/dna-tests-fail-to-wininsurer-consent-with-lives-at-stake.html, archived at http://perma.cc/PGH8-S76G.

33. Id. 
whose insurance companies would not pay for the screening; the monopoly also caused problems for patients who feared that the test may be inaccurate and desired a second opinion. ${ }^{34}$

BRACAnalysis was considered a preventive screening and was therefore covered by many health insurance carriers. ${ }^{35}$ If, however, Myriad Genetics did not have a contract with a particular health insurance company, patients were required to pay out of pocket. ${ }^{36}$ With other medical procedures and preventive treatments, if an insurance company is not under contract with a particular pharmaceutical or biotech company, the insurance carrier typically has a contract with another provider that can provide the patient with a similar service. ${ }^{37}$ In the case of BRCA gene mutation testing, Myriad was the only provider of the test. ${ }^{38}$ Patients were left with no other options for the potentially lifesaving screening. ${ }^{39}$

One of the main reasons that insurance companies were hesitant to enter into contracts with Myriad for the BRCA screening was the lack of scientific evidence demonstrating the effectiveness of the genetic tests. ${ }^{40}$ Insurance companies were fearful the test would fail to detect a mutation or would give false positives. ${ }^{41}$ The concern was that genetic testing would lead patients and their providers down "blind alleys," which would result in increased healthcare costs across the board. ${ }^{42}$ High costs could come both from unnecessary treatments in cases where the test gave a false positive and from treatment for advanced conditions that failed to be detected by the screening. ${ }^{43}$

Fear of increased health care costs was also the leading reason that government-funded insurance programs were hesitant to cover Myriad's BRACAnalysis. ${ }^{44}$ As a way to discourage this preventive screening in Medicaid patients, many state Medicaid programs offered Myriad low reimbursement rates for BRACAnalysis. ${ }^{45}$ The low reimbursement rates discouraged Myriad from entering into a contract with the state, leaving Medicaid patients without insurance coverage for the expensive test. ${ }^{46}$ The ramifications of low coverage rates in the Medicaid population was significant because it left low income

34. Id.; see also Colao, supra note 18 (noting that BRACAnalysis has a three percent error rate in some cases).

35. Id.

36. Id.

37. Methodology for Health Costs for Consumers, NH HEALTH Cost, http://nhhealthcost. nh.gov/methodology-health-costs-consumers (last visited Dec. 19, 2014), archived at http://perma.cc/596R-CRCJ.

38. Laueman, supra note 32.

39. Id.

40. Id.

41. Id.

42. $I d$.

43. $I d$.

44. Id.

45. Id.

46. Id. 
populations, unable to pay out of pocket, with no alternative. ${ }^{47}$

However, despite some of Myriad's shortcomings, since developing the BRACAnalysis test "Myriad has worked to have its tests covered by most private and public payers, and estimates that [ninety-five] percent of U.S. patients have access to its breast cancer test." preventive screening, Myriad offers subsidization for the cost of testing in patients who have no health coverage. ${ }^{49}$ Nevertheless, those individuals who are covered by health plans that do not cover the test are forced to pay out of pocket in a market where the Myriad test is the only option. ${ }^{50}$

2. Individuals Effected by Myriad's Monopoly.-Much of the recent media portrayal of BRACAnalysis as a lifesaving genetic test has been centered on actress Angelina Jolie. ${ }^{51}$ On February 2, 2013, Jolie began the process of having a double mastectomy and reconstructive surgery after learning from BRACAnalysis that she was a carrier of the BRCA mutation. ${ }^{52}$ Jolie decided to have the BRACAnalysis test because her mother died of breast cancer at the age of $56 .{ }^{53}$ Jolie was told that she had an eighty-seven percent risk of developing breast cancer and a fifty percent risk of developing ovarian cancer. ${ }^{54}$ As a result of Jolie's mastectomy, her risk of developing breast cancer decreased to just under five percent. ${ }^{55}$

However, as Jolie acknowledged, the cost of the BRACAnalysis screen is expensive and "at more than $\$ 3,000$ in the United States, remains an obstacle for many women." "W6 While Jolie was one of the fortunate women who were able to afford the screening and take preventive treatment measures to lower her risk, not

\section{Id.}

48. Id.

49. Myriad Promise, MYRIAD, https://www.myriad.com/patients/myriadpromise/ (last visited Jan. 27, 2014), archived at http://perma.cc/9HU8-XMKD.

50. Laueman, supra note 32.

51. See Holly Yan, What's the Gene that Led to Angelina Jolie's Double Mastectomy, CNN (May 16, 2013, 10:05 AM), http://www.cnn.com/2013/05/14/health/jolie-what-is-brca/, archived at http://perma.cc/B6PZ-WHDK (noting that Jolie's preventive mastectomy raised questions about the BRCA gene); see also Sydney Lupkin, Why the Angelina Effect is at Odds With New Guidelines, ABC NEWs (Dec. 23, 2012), http://abcnews.go.com/Health/brca-testing-guidelinescounter-angelina-jolie-effect/story?id=21315733, archived at $\mathrm{http} / /$ perma.cc/Z73R-ZU58 (noting that the "the Angelina Effect" led many women to seek genetic testing, even though the United States Preventive Services Task Force recommends the test only for women with a family history of breast cancer).

52. Ed Payne, Angelina Jolie Undergoes Double Mastectomy, CNN (May 16, 2013, 8:09 AM), http://www.cnn.com/2013/05/14/showbiz/angelina-jolie-double-mastectomy/, archived at http://perma.cc/LZ73-AV5D.

53. Angelina Jolie, My Medical Choice, N.Y. TIMES (May 14, 2013), http://www.nytimes. com/2013/05/14/opinion/my-medical-choice.html?_r=0, archived at $\mathrm{http}: / /$ perma.cc/YDK7-JH7W.

54. Id.

55. Id.

56. Id. 
all women are this lucky. ${ }^{57}$ One such woman was Genae Girard, who received a diagnosis of breast cancer in 2006. ${ }^{58}$ Following her diagnosis, Girard decided to undergo the BRACAnalysis screening to determine if her cancer was genetic, thereby putting her at an increased risk for ovarian cancer. ${ }^{59}$ The BRACAnalysis came back positive for a BRCA mutation, and Girard sought a second opinion to confirm the results of the test before undergoing a dramatic hysterectomy that would make her unable to have children. ${ }^{60}$ However, because Myriad held the patent to the BRCA genes, no second opinion was available. ${ }^{61}$

Similarly, Lisbeth Cerianai, a single mother who was diagnosed with bilateral breast cancer at the age of forty-two, also wanted to undergo the BRACAnalysis screening to determine her increased risk of ovarian cancer. ${ }^{62}$ Cerianai was a Massachusetts Medicaid recipient and Medicaid would only cover the cost of the BRACAnalysis test if provided by a contracted provider. ${ }^{63}$ Myriad was the only lab able to provide the test and refused to contract with Massachusetts Medicaid because the reimbursement rates were too low. ${ }^{64}$ The cost of Myriad's BRACAnalysis was $\$ 3225 .{ }^{65}$ Medicaid offered to pay Myriad only $\$ 1599$, and Myriad refused a contract with the state. ${ }^{66}$ If Ceriani wanted the test, she would have to pay the $\$ 3225$ out of pocket. ${ }^{67}$

C. The United States Supreme Court: Association of Molecular Pathology v. Myriad Genetics

Backed by women such as Lisbeth Ceriani and Genae Girard, as well as physicians and various medical researchers, the American Civil Liberties Union and the Public Patent Foundation filed suit alleging Myriad's patents on the BRCA genes should be invalidated as products of nature. ${ }^{68}$ The suit made its way to the United States Supreme Court, ending Myriad's ongoing battle to defend its

57. See, e.g., John Schwartz, Cancer Patients Challenge the Patenting of a Gene, N.Y. TIMES (May 12, 2009), http://www.nytimes.com/2009/05/13/health/13patent.html, archived at http:// perma.cc/69HM-PXXV; Lisbeth Ceriani, BRCA-Plaintiff Statements, AM. CIVIL LIBERTIES UNION (May 12, 2009), https://www.aclu.org/free-speech_womens-rights/brca-plaintiff-statements\# ceriani, archived at http://perma.cc/UG9W-X8F5.

58. Schwartz, supra note 57.

59. Id.

60. Id.

61. Id.

62. Ceriani, supra note 57.

63. Id.

64. Id.

65. Id.

66. Id.

67. Id.

68. Supreme Court Invalidates Patents on Breast and Ovarian Cancer Genes, AM. CIvIL LIBERTIES UNION (June 13, 2013), https://www.aclu.org/womens-rights/supreme-court-invalidatespatents-breast-and-ovarian-cancer-genes, archived at http://perma.cc/SVW3-RUHJ. 
intellectual property rights on the BRCA genes.

1. The Path to the United States Supreme Court.-For women like Ceriani and Gerard, the Myriad decision provided hope that the preventive genetic testing market would expand to offer more testing options at a lower cost. After Myriad discovered the precise locations of the BRCA genes, it was not the only company initially to offer BRCA testing. ${ }^{69}$ "The University of Pennsylvania's Genetic Diagnostic Laboratory [("GDL")] and others provided genetic testing services to women." ${ }^{, 70}$ However, after Myriad learned that other companies were conducting genetic tests on the BRCA genes, it notified the companies that they were infringing on the Myriad patents. ${ }^{71}$ As a result, GDL halted genetic tests on the BRCA genes. ${ }^{72}$ Myriad also settled several patent infringement suits against other entities performing similar testing. ${ }^{73}$ After Myriad became the sole company to provide BRCA testing, "medical patients, advocacy groups, and . . . doctors" filed suit to invalidate Myriad's patents under the Patent Act. ${ }^{74}$

2. Association of Molecular Pathology v. Myriad Genetics.- -Under section 101 of the Patent Act, "whoever invents or discovers any new and useful . . . composition of matter, or any new and useful improvement thereof, may obtain a patent." "75 However, "phenomena of nature, although just discovered, mental processes, and abstract intellectual concepts are not patentable as they are basic tools of scientific and technological work." ${ }^{\prime 76}$ This exception is necessary in scientific and biotechnological patenting because without it, future innovation based on these processes is inhibited. ${ }^{77}$ It was on this foundation that the United States Supreme Court unanimously held that Myriad's patents were invalid as products of nature and thus not eligible for patent protection. ${ }^{78}$ The Court found that isolating the BRCA1 and BRCA2 genes from the rest of the human genome through a separation technique did not make the genes patentable. ${ }^{79}$ The Court held that "[t]he location and order of the nucleotides existed in nature before Myriad found them. Myriad [did not] create or alter the genetic structure of DNA. Instead, Myriad's principal contribution was uncovering the precise location and genetic sequence of the BRCA1 and BRCA2 genes within the chromosomes." ${ }^{80}$ While this isolation led to the discovery of a gene that revealed

69. Ass'n for Molecular Pathology v. Myriad Genetics, 133 S. Ct. 2107, 2114 (2013).

70. Id.

71. Id.

72. $I d$.

73. $I d$.

74. Id.

75. The Patent Act, 35 U.S.C. $\S 101$ (2013).

76. Gottschalk v. Benson, 409 U.S. 63, 67 (1972).

77. Ass' $n$ for Molecular Pathology, 133 S. Ct. at 2116; see also Diamond v. Chakrabarty, 447 U.S. 303, 309 (1980) (explaining that patents exist to promote creation and products of nature are not created).

78. $I d$.

79. Id. at 2120 .

80. Id. at 2114 . 
a woman's predisposition to breast cancer, innovative discovery is not sufficient for patent rights. ${ }^{81}$

It is important to note that the Court made clear that the holding of Myriad is limited to the patentability of human genes and does not apply to "method claims, patents on new applications of the knowledge about BRCA1 and BRCA2 genes, or the patentability of DNA in which the order of the naturally occurring nucleotides has been altered." 82 This limitation on the application of the decision leaves open the question of "whether the concepts in the decision [will be] extrapolated to other drug discovery techniques such as stem cells." ${ }^{.83}$

\section{The Implications of Myriad on Affordability of Preventive and Personalized Care Under the ACA}

The United States Supreme Court's invalidation of Myriad's patents on the BRCA genes opened up the genetic testing landscape for other providers to begin offering screenings for the BRCA mutations. ${ }^{84}$ While the full results of the decision have yet to be seen, early indications of other companies beginning to offer the screening are promising and suggest that the price of genetic testing for predisposition to breast cancer could begin to decrease dramatically.

1. Political Landscape During the Myriad Decision.-On March 23, 2010, three years prior to the Myriad decision, President Barack Obama signed into law the Patient Protection and Affordable Care Act with the three main objectives of improving the quality of healthcare, lowering healthcare costs, and increasing access to healthcare. ${ }^{85}$ With several provisions dedicated to these objectives,

[t]he Act will promote prevention, wellness, and the public health and provides unprecedented funding commitment to these areas. It directs the creation of a national prevention and health promotion strategy that incorporates the most effective and achievable methods to improve the health status of Americans and reduce the incidence of preventable illness and disability in the United States. ${ }^{86}$

The decision of the United States Supreme Court to invalidate the patenting of human genes had repercussions far beyond the scientific and legal

81. Id.

82. Id.

83. Carolyn Y. Johnson, No Patenting of Genes, Justices Rule, Bos. GloBE (June 13, 2013), http://www.bostonglobe.com/2013/06/13/supreme-court-rules-human-genes-cannotpatented/TB4XFUuICEiiQC6bdQqSkL/story.html, archived at http://perma.cc/MLZ5-SVY9.

84. Lee, supra note 4.

85. Key Features of the Affordable Care Act, DeP'T of Health \& Human Serv., http://www.hhs.gov/healthcare/facts/timeline/ (last visited Nov. 23, 2013), archived at http://perma.cc/DX38-2WSL.

86. Read the Law: The Affordable Care Act, Section by Section, DeP'T OF HeAlth \& SERV., http://www.hhs.gov/healthcare/rights/law/index.html (last visited Oct. 8, 2013), archived at http://perma.cc/45RS-XBH7. 
communities. In June 2013, when Myriad was decided, the political landscape of America was very much centered on healthcare reform, the ACA, and the goal of increasing accessibility and affordability of medical treatments for all Americans ${ }^{87}$ With the Myriad decision, the United States Supreme Court, albeit inadvertently, opened up one small avenue that allowed patients more affordable means of accessing preventive testing for breast and ovarian cancers. ${ }^{88}$

2. Key Provisions of the ACA Enhanced by Myriad.-One of the key defining features of the ACA is the establishment of the Health Insurance Marketplace ("The Marketplace"). ${ }^{89}$ The Marketplace is comprised of a series of state and federally run insurance exchanges that offer individual coverage for people who are unable to receive insurance through their employer. ${ }^{90}$ Under the ACA, insurance plans purchased on the exchange must cover essential health benefits. ${ }^{91}$ Outlined in Title I of the Act, "Quality and Affordable Health Care for All Americans," essential health benefits include the coverage of preventive and wellness services and place cost-sharing limits on these benefits for the patient. ${ }^{92}$ The ACA includes preventive BRCA screenings for women in its definition of "preventive health services" by requiring that a health insurer offering a plan on The Marketplace provide coverage, without cost sharing requirements, on all services that the United States Preventive Service Task Force ("USPSTF") has given an "A" or "B" rating. 93

The USPSTF breaks down its recommendations into alphabetical classifications based on the importance of the recommendation in promoting health. ${ }^{94}$ According to the Task Force, Grade A recommendations mean that there is a high certainty of substantial benefit and the USPSTF recommends the service. ${ }^{95}$ Similarly, Grade B recommendations mean that there is moderate certainty that the benefit is moderate to substantial. ${ }^{96}$ According to USPSTF, BRCA screening and counseling about the results of the screening are a Grade B recommendation and are therefore covered under the ACA with no patient cost

87. Ass'n for Molecular Pathology v. Myriad Genetics, 133 S. Ct. 2107 (2013).

88. See Lee, supra note 4.

89. U.S. Ctrs. for Medicare \& Medicaid Servs., A One-Page Guide to the Health Insurance Marketplace, HEALTHCARE.GOV, https:/www.healthcare.gov/what-is-the-health-insurancemarketplace (last visited Mar. 8, 2014), archived at http://perma.cc/W7JR-JZXW.

90. Aetna, Inc., Health Care Reform: What is a Health Insurance Exchange?, AETNA, http://www.aetna.com/health-reform-connection/reform-explained/video-exchanges.html (last visited March 8, 2014), archived at http://perma.cc/RX4D-JR7W.

91. 42 U.S.C. $\S 18022$ (2010).

92. Id.

93. 42 U.S.C. $§ 300 \mathrm{gg}-13$ (2010).

94. Grade Definitions, U.S. Preventive Servs. TASK Force, http://www.uspreventiveservicestaskforce.org/uspstf/grades.htm (last visited Nov. 23, 2013), archived at http://perma.cc/NST4-NACK.

95. Id.

96. Id. 
sharing. ${ }^{97}$ "The USPSTF recommends that women whose family history is associated with an increased risk for deleterious mutations in BRCA1 or BRCA2 genes be referred for genetic counseling and evaluation for BRCA testing."

Because insurers are now required to cover BRCA screening under the ACA, insurers will look to enter into the lowest contract price possible to provide the test. ${ }^{99}$ This is important in light of another key feature of the ACA, the individual mandate. Under the individual mandate, all Americans are required to maintain minimum essential health coverage. ${ }^{100}$ This requirement greatly "broaden[s] the health insurance risk pool to include healthy individuals."101 Because everyone will be required to pay insurance premiums, the cost of covering the required minimum essential benefits will be passed on to the entire risk pool. ${ }^{102}$ Therefore, it is beneficial not only to the insurance company, but also to the insured, for alternative BRCA screenings to be available on the market to drive down the cost. The Myriad decision has the potential to directly affect the cost of BRCA screenings because the invalidation of gene patents will allow companies other than Myriad to develop a test and potentially offer it at a reduced price. This cost savings has the potential to lower premiums for the insured.

In addition to cost savings on premiums, uninsured patients will benefit from the reassurance that they will not have to pay upwards of $\$ 3000$ for the test. ${ }^{103}$ Furthermore, patients facing the life altering decision of having a hysterectomy or mastectomy will have the option of seeking a second opinion. A second opinion could potentially save insurers from the costs of unnecessary surgery.

As well as private insurance companies being required to cover BRCA screenings for insurance policies purchased on the exchange, government-funded programs such as Medicare and Medicaid will also be required to cover the tests. ${ }^{104}$ Because Medicare and Medicaid are government programs funded in part

97. USPSTF $A$ and $B$ Recommendations, U.S. Preventive SERVs. TASK Force, http://www.uspreventiveservicestaskforce.org/uspstf/uspsabrecs.htm (last updated Feb. 2013), archived at http://perma.cc/D6YA-JCKK.

98. Genetic Risk Assessment and BRCA Mutation Testing for Breast and Ovarian Cancer Susceptibility, U.S. PREVENTIVE SERVS. TASK FORCE, http://www.uspreventiveservicestaskforce. org/uspstf05/brcagen/brcagenrs.htm (last updated September 2005), archived at http://perma.cc/ ZV6E-G9PG.

99. See generally Matthew Herper, Inside the Secret World of Drug Company Rebates, FORBES (May 10, 2012, 9:54 AM), http://www.forbes.com/sites/matthewherper/2012/05/10/whyastrazeneca-gives-insurers-60-discounts-on-nexiums-list-price/, archived at $\mathrm{http}$ ://perma.cc/3KPFSVT6 ("drug companies are constantly negotiating, not with individuals but with payers-Medicare, Medicaid, insurers such as United Health Care and Aetna . ...").

100. 42 U.S.C. $\S 18091$ (2013).

101. $I d$.

102. Nat'l Fed'n of Indep. Bus. v. Sebelius, 132 S. Ct. 2566, 2585 (2012).

103. See Patricia Rensende, Quest Rolls out a Cheaper Test for Cancer Genes, Bos. Bus. J. (Oct. 16, 2013, 2:07 PM), http://www.bizjournals.com/boston/blog/bioflash/2013/10/quest-genepatent.html?page=all, archived at $\mathrm{http}: / /$ perma.cc/ESP3-GPKX.

104. U.S. Ctrs. for Medicare \& Medicaid Servs., Prevention, MediCAID.gOv, http://www. 
by citizen tax dollars, any decrease in cost of BRCA testing on the market could mean less expense for taxpayers. ${ }^{105}$ While Myriad has refused to accept many government-funded programs' reimbursement rates, ${ }^{106}$ the Myriad decision could foster the growth of competitors who would be more willing to offer testing to government insured patients at a reduced cost.

3. The Effect on Genetic Screening for Other Conditions.-While BRCA screening coverage is required under the ACA, there are many other life threatening conditions for which genetic screening is not considered a minimum essential benefit. The invalidation of gene patents will have the potential to open up the market for other genetic tests by potentially invalidating patents held on disease-causing genetic mutations. The invalidation of these patents could lead to other biotech firms developing tests for the condition, offering patients more options in the marketplace and driving costs down.

For many genetic conditions, insurance companies have refused to cover the cost of genetic tests but have been willing to pay for more expensive alternatives. For example, the major insurer Blue Cross Blue Shield will not cover the cost of a genetic test to screen for the inherited heart condition hypertrophic cardiomyopathy. ${ }^{107}$ The genetic test is a one-time cost of $\$ 500 .{ }^{108}$ However, as an alternative, Blue Cross Blue Shield will pay \$2000 a year for the patient to receive an annual heart scan to look for the condition. ${ }^{109}$

Despite insurance companies' refusal to cover them, genetic tests are increasing in popularity and are likely to continue to do so under a health reform that is focused on cost savings stemming from preventive care. ${ }^{110}$ In the next ten years, spending on genetic tests is expected to increase over five times, from $\$ 5$ billion to over $\$ 25$ billion per year. ${ }^{11}$ Just paying the upfront cost of a single genetic test can eliminate the costs associated with a lifetime of annual tests and treatments, costs that again will be passed on to all individuals in the risk pool; for those patients who are found not to have a genetic mutation, a one-time genetic screening can eliminate the cost of all future testing related to the genetic condition.

4. The BRCA Screening Industry Post-Myriad.-In the five months since the Myriad decision was issued, additional companies have begun to offer BRCA screening for a lower cost. Currently, Myriad's test BRACAnalysis costs

medicaid.gov/Medicaid-CHIP-Program-Information/By-Topics/Benefits/Prevention.html (last visited Nov. 23, 2013), archived at http://perma.cc/EMJ9-9L2D.

105. U.S. Ctrs. for Medicare \& Medicaid Servs., How is Medicare Funded?, MEDICARE.GOV, http://www.medicare.gov/about-us/how-medicare-is-funded/medicare-funding.html (last visited Nov. 23, 2013), archived at http://perma.cc/R2J7-FNJD.

106. See generally Ass'n for Molecular Pathology v. Myriad Genetics, 133 S. Ct. 2107 (2013).

107. Laueman, supra note 32.

108. Id.

109. Id.

110. Id.

111. Id. 
between $\$ 3000$ and $\$ 4000$ on average for a woman who is uninsured. ${ }^{112}$ In October 2013, five months after Myriad, Quest Diagnostics, Inc., announced that they would begin offering a BRCA screen called BRACAdvantage. ${ }^{113}$ Quest Diagnostics is the largest provider of medical laboratory testing in the United States and services over fifty percent of the nation's doctors. ${ }^{14}$ Quest is also the largest competitor to go head-to-head with Myriad on BRCA screening since the United States Supreme Court decision in June. ${ }^{115}$

Quest's BRACAdvantage will be offered at a cost of $\$ 2500$ and, while still expensive, it offers a significant savings compared to the "almost $\$ 3,400$ that Medicare pays for the most comprehensive version of a test from Myriad."116 Analysts have suggested that this increased competition in the market will lead to "[p]rivate insurer re-evaluation [that] may drive down the price for Myriad's BRCA test by as much as [fifty] percent over the next two years." 117 Additionally, in an anticipatory move, Quest filed a complaint in federal court in California that "it believes Myriad will bring a patent-infringement lawsuit if it starts selling its BRCA test products." 118 Quest is seeking a court order that BRACAdvantage does not infringe on any valid Myriad patents. ${ }^{119}$

While other companies have begun to offer BRCA screening, Myriad has not gone down without a fight. Within hours of the United States Supreme Court ruling, Ambry Genetics and its closely held company, Gene by Gene, Ltd., also began offering BRCA testing at a much lower cost than the Myriad test. ${ }^{120}$ Ambry's test now costs $\$ 2200$ and Ambry is including the BRCA screen free on its other genetic tests. ${ }^{121}$ Gene by Gene is offering the BRCA testing for as low as \$995. ${ }^{122}$ Shortly after Ambry and Gene by Gene began offering the tests, Myriad filed a patent infringement lawsuit against the companies alleging that the tests infringe on ten patents claimed by Myriad based on the cDNA used in the testing. ${ }^{123}$ Ambry counterclaimed against Myriad that its infringement lawsuit is

112. Rensende, supra note 103.

113. Id.

114. Ryan Jaslow, Quest Diagnostics Adds BRCA Gene Testing: Should More Women get the Test?, CBS NEws (Oct. 15, 2013, 12:33 PM), http://www.cbsnews.com/news/quest-diagnosticsadds-brca-gene-testing-should-more-women-get-test/, archived at http://perma.cc/U65Z-EDQN.

115. Robert Langreth, Quest Introduces Breast-Cancer Gene Test Rivaling Myriad, BLOOMBERG (Oct. 15, 2013, 4:14 PM), http://www.bloomberg.com/news/2013-10-15/questintroduces-breast-cancer-gene-test-rivaling-myriad.html, archived at $\mathrm{http}: / /$ perma.cc/PL9L-EKDQ.

116. Id.

117. Id. (internal quotations omitted).

118. Id.

119. Id.

120. Langreth, supra note 115.

121. Id.

122. Id.

123. Ambry Genetics Countersues Myriad Genetics Alleging Antitrust Violations, GENOMEWEB (Aug. 6, 2013), http://www.genomeweb.com/clinical-genomics/ambry-geneticscountersues-myriad-genetics-alleging-antitrust-violations, archived at http://perma.cc/J2V3-NV63; 
"in violation of the Sherman Antitrust Act because the asserted claims against Ambry are invalid under two [United States] Supreme Court decisions and Federal Circuit authority." 124

On February 7, 2014, the lawsuit against Gene by Gene was dropped and the parties entered into a settlement agreement. ${ }^{125}$ Under the agreement, Gene by Gene will stop selling and marketing all BRCA tests in North America. ${ }^{126}$ However, the company is allowed to sell the tests in all other countries worldwide. ${ }^{127}$ The agreement lasts until February 6, 2016, when Myriad's BRCA patents expire. ${ }^{128}$

While Myriad's case against Gene by Gene did not make it through the court system to determine whether or not Myriad's reign over BRCA testing stands, it is positive to see that other biotechnological companies are beginning to offer genetic screening for the BRCA mutation at reduced prices. This competition gives hope that the cost of the test and other similar genetic tests can be lowered. Reduced costs to insurance companies, patients, and taxpayers will help to achieve key provisions of the ACA regarding preventive care.

\section{Stem Cells: The PATENTING LANDSCAPE}

The opinion issued by the Court in Myriad was a narrow one and the Court did not extend its holding to patented method claims, applications of scientific knowledge, or cases of altered DNA. ${ }^{129}$ Additionally, the opinion applied only to patents on isolated DNA and not other patented biological materials. ${ }^{130}$ However, because of the scientific composition of the BRCA genes, the historical background behind the patenting of genes, and Myriad's monopoly of the genetic testing landscape, legal scholars have begun to question how the United States Supreme Court's view of Myriad's patents could be applied to other biotech patents in the near future, particularly stem cells. ${ }^{131}$

see generally Esha Dey, Court Denies Myriad Motion to Block Rival Genetic Tests, REUTERS (Mar. 11, 2014, 9:01 AM), http://www.reuters.com/article/2014/03/11/us-myriadgenetics-lawsuitidUSBREA2A0NM20140311, archived at $\mathrm{http}: / /$ perma.cc/5MXN-VBNL (noting that Myriad was denied an injunction to stop Ambry from offering a BRCA screening test on the grounds that the company was unlikely to succeed on the merits of the case).

124. $I d$.

125. BRCA Patent Owners and Gene by Gene, Ltd. Resolve Patent Suit, MYRIAD (Feb. 7, 2014), http://investor.myriad.com/releasedetail.cfm?ReleaseID=824154, archived at $\mathrm{http}: / /$ perma. cc/F6BA-MKFS.

126. Id.

127. Id.

128. $I d$.

129. Ass'n for Molecular Pathology v. Myriad Genetics, Inc., 133 S. Ct. 2107, 2119-20 (2013).

130. Johnson, supra note 83.

131. See generally Hank Greely, Myriad Decision Invoked in Appeal of Suit to Invalidate Embryonic Stem Cell Patent Claims, STANFORD LAW School: THE CTR. FOR LAW AND THE BIOSCIENCES (July 4, 2013), http://blogs.law.stanford.edu/lawandbiosciences/2013/07/04/myriad- 


\section{A. A Scientific Background on Stem Cells}

"Stem cells are the body's raw materials - cells from which all other cells with specialized functions are generated." ${ }^{132}$ Stem cells, unlike other cells in the human body, have the ability to develop into many different cell types and can renew themselves through cell division. ${ }^{133}$ Additionally, stem cells have the ability to be induced to become new tissue, such as organs. ${ }^{134}$

There are three main types of stem cells: embryonic stem cells, adult stem cells, and induced pluripotent stem cells. ${ }^{135}$ Stem cells are unique for three reasons: they are capable of long-term division and renewal; they are unspecialized, meaning they are not one distinct cellular type; and they can become many specialized cell types. ${ }^{136}$

Human embryonic stem cells ("hES cells") are the cells that are found in three to five day embryos. ${ }^{137}$ These cells give rise to the entire human body, from organs, to tissues, to sex cells. ${ }^{138}$ For research purposes, embryonic stem cells are derived from eggs produced from in vitro fertilization and then donated for research. ${ }^{139}$ Adult stem cells, found in many different organs and tissues in the body, have the primary role of repairing damaged tissue. ${ }^{140}$ In contrast to hES cells, adult stem cells do not possess the same ability to give rise to a wide range of cells in the body; these stem cells are usually limited to producing cells of the same type. ${ }^{141}$ Finally, induced pluripotent stem cells are cells created through a process of genetic reprogramming. ${ }^{142}$ "By altering the genes in the adult cells, researchers can reprogram the cells to act similarly to embryonic stem cells." ${ }^{143}$

Although stem cell research is still a relatively new field, there have been

decision-invoked-in-appeal-of-suit-to-invalidate-embryonic-stem-cell-patent-claims/, archived at http://perma.cc/DP6F-92FD; Ryan Davis, Stem Cell Patent Case Will Be Early Test of Myriad's Reach, LAw360 (July 10, 2013, 8:55 PM), http://www.law360.com/articles/456259/stem-cellpatent-case-will-be-early-test-of-myriad-s-reach, archived at http://perma.cc/2XHS-RT4Z.

132. Mayo Foundation for Medical Education and Research, Stem Cells: What They Are and What They Do, MAYOCLINIC, http://www.mayoclinic.com/health/stem-cells/CA00081 (last visited Nov. 23, 2013), archived at http://perma.cc/Y7BT-WHFZ.

133. U.S. Dep't of Health and Human Services, Stem Cell Information: Stem Cell Basics, NAT'L INST. OF HEALTH, http://stemcells.nih.gov/info/basics/pages/basics1.aspx (last visited Oct. 9, 2013), archived at http://perma.cc/CAR6-5HE6.

134. Id.

135. $I d$.

136. $I d$.

137. Id.

138. Id.

139. Id.

140. Id.

141. Id.

142. Id.

143. Id. 
promising results that suggest that these cells can possibly be used to treat chronic diseases such as cancer, neurodegenerative disorders, and diabetes. ${ }^{144}$ Additionally, scientists are hopeful that human embryonic stem cells can someday be used to replace entire organs. ${ }^{145}$

\section{B. The Current Stem Cell Patenting Landscape}

1. The History of Stem Cells Research.-While stem cells have the potential to treat and cure many of the most common chronic conditions, further research and development on stem cells has been hindered by the current stem cell patent landscape. ${ }^{146}$ Much like the discovery of the BRCA genes, there was also a race among scientists to develop methods to isolate animal, primate, and human stem cells. ${ }^{147}$ The research that sparked an interest in stem cells began in $1998 .{ }^{148}$ At that time, California-based Geron Corporation ("Geron"), a biopharmaceutical company, funded studies to grow hES cells in the laboratory. ${ }^{149}$ Two research groups received Geron funding, including groups led by Dr. James Thomson at the University of Wisconsin and Dr. John Gearhardt at Johns Hopkins University. ${ }^{150}$ Both Dr. Thomson and Dr. Gearhardt "independently announced the isolation of human stem cells" in November of 1998. ${ }^{151}$ Dr. Thomson's lab used "spare human embryos provided by the University of Wisconsin's infertility clinic" while Dr. Gearhart used tissue from aborted fetuses. ${ }^{152}$

Dr. Thomson was awarded several patents related to both hES cells and their isolation methods. ${ }^{153}$ Dr. Thomson assigned the patents to the Wisconsin Alumni Research Foundation ("WARF"), effectively giving WARF ownership rights to all $\mathrm{hES}$ cells and their products. ${ }^{154}$ Some of the stem cell patents assigned to WARF include United States Patent Number 5,843,780, United States Patent

144. Jana E. Harris, Reprogramming the Future of Stem Cell Patents, 18 AnNals Health L. AdVANCE DiRective 10, 10 (2008).

145. Id.

146. John Miller, Note, A Call to Legal Arms: Bringing Embryonic Stem Cell Therapies to Market, 13 AlB. L.J. SCI. \& TECH. 555, 556 (2003).

147. Brief for the Appellant at 4, Consumer Watchdog v. Wis. Alumni Research Found., (Fed. Cir. July 2, 2013) No. 2013-1377.

148. Ronald M. Green, The Stem-Cell Debate, NOVA OnLINE (Nov. 2001), http://www.pbs. $\mathrm{org} / \mathrm{wgbh} / \mathrm{nova} / \mathrm{miracle} / \mathrm{stemcells.html}$, archived at http://perma.cc/QW87-PTYH.

149. $I d$.

150. Id.

151. EBSCO Publ'g, History of Stem Cell Research, EBSCO Host CONNECTION, http://connection.ebscohost.com/health/stem-cell-research/history-stem-cell-research (last visited Jan. 27, 2014), archived at http://perma.cc/3ZLY-GRX2.

152. Green, supra note 148.

153. Brief for the Appellant at 7, Consumer Watchdog v. Wis. Alumni Research Found., (Fed. Cir. July 2, 2013) No. 2013-1377.

154. Id. 
Number 6,200,806, and United States Patent Number 7,029,913. ${ }^{155}$ These patents "claim[ ] a purified preparation of primate ES cells and a method for isolating them ... . [and] a purified preparation of pluripotent human ES cells and their method of derivation," "156 meaning that WARF has ownership rights over all embryonic stem cells and the products created from them. ${ }^{157}$

In exchange for funding, Geron required the "exclusive licensing of the technologies" developed by Dr. Thomson. ${ }^{158}$ As a result, WARF entered into an agreement with Geron, giving Geron the exclusive right to turn the cells into a commercial treatment. ${ }^{159}$ WARF later sued Geron to regain the commercial rights. ${ }^{160}$ All rights were returned to WARF with the exception of the right to create treatments from nerve cells, heart tissue, and the pancreas. ${ }^{161}$ Although Geron developed a stem cell spinal cord treatment, the company faced financial problems and halted all further stem cell research in 2011. ${ }^{162}$ Geron still has the exclusive right to the nerve, heart, and pancreas treatments that could result in many lifesaving treatments for chronic conditions. ${ }^{163}$ Geron's monopoly over these cells will decrease the competition among biotech firms who are unwilling to go through the difficult process to enter into licensing agreements with Geron. ${ }^{164}$

2. Stem Cell Patents: Licensing and the Patent Thicket.- "Given the broad scope of the patent claims over the development of hES[ ] cells and over hES[ ] [cells] themselves, WARF is able to prohibit any derivation, use, importation, or research into hES[ ] [cell] lines in the United States . . .."165 However, WARF has been willing to license its patents to other players in the biotech industry. ${ }^{166}$ While this has slightly opened up the market for additional biotech companies

155. Burning Bridges, NATURE BIOTECHNOLOGY (2007), http://www.nature.com/ nbt/journal/v25/n1/full/nbt0107-2.html, archived at http://perma.cc/6LLY-L374.

156. Id.

157. Miller, supra note 146.

158. Green, supra note 148.

159. Antonio Regalado \& David Hamilton, How a University's Patents May Limit Stem-Cell Research, CTR. FOR GENETICS AND SOC'Y (July 18, 2006), http://www.geneticsandsociety. org/article.php?id=1896, archived at http://perma.cc/6LFQ-NGV4.

160. Id.

161. Id.

162. Linda A. Johnson, Geron Halting Stem Cell Research, Laying off Staff, USA TODAY (Nov. 15, 2011, 1:18 PM), http://usatoday30.usatoday.com/news/health/story/health/story/2011-11$15 /$ Geron-halting-stem-cell-research-laying-off-staff/51215752/1, archived at http://perma.cc/U2UC-KT8N.

163. Regalado \& Hamilton, supra note 159.

164. Miller, supra note 146, at 557.

165. Jenny Shum, Moral Disharmony: Human Embryonic Stem Cell Patent Laws, WARF, and Public Policy, 33 B.C. InT'L \& COMP. L. REV 153, 173 (2010).

166. Karl Bergman \& Gregory D. Graff, The Global Stem Cell Patent Landscape: Implications for Efficient Technology Transfer and Commercial Development, 25 NATURE BIOTECHNOLOGY 419, 419 (2007). 
and academic institutions to begin research and development of possible stem cell therapies, the cost of licensing is high and has significantly driven up the cost of stem cell research. ${ }^{167}$

As of 2007, WARF charged anywhere from $\$ 75,000$ to $\$ 400,000$ for a licensing agreement. ${ }^{168}$ Additionally, companies entering into an agreement with WARF must also pay annual fees and royalties on any sales from potentially commercial products. ${ }^{169}$ Unlike many other patent holders, WARF also charges a fee "per cell line, per investigator." ${ }^{170}$ For small research programs and biotech firms, this rapidly increases the costs of conducting stem cell research. ${ }^{171}$ As a result of its high licensing costs, WARF only has licensing agreements in place with approximately twenty-nine commercial companies, ${ }^{172}$ including pharmaceutical giant Pfizer. ${ }^{173}$

While WARF does not charge academic institutions to research stem cell lines, this does little to help to the furtherance of commercial medical products. Beginning in 2007, WARF implemented a new policy that allowed biopharmaceutical companies to sponsor embryonic stem cell research in academic institutions without a license. ${ }^{174}$ While this allows these companies to conduct research without the high licensing fees they would pay in their own lab, the companies must still pay the fees as soon as they choose to remove the research from the university or as soon as they develop a commercial product. ${ }^{175}$

In addition to hurdles created by WARF's high licensing fees, there are additional problems in the current stem cell patent landscape that make further research and development in the industry difficult. One such problem is the existence of a patent thicket or anti-commons. ${ }^{176}$ "In a patent thicket, the existence of many overlapping patent claims can cause uncertainty about freedom to operate, impose multiple layers of transaction costs and stack royalty payments

167. Susan Decker, Gene Patent Case Fuels U.S. Court Test of Stem Cell Right, BLOOMBERG (Jan. 6, 2014, 12:01 AM), http://www.bloomberg.com/news/2014-01-06/gene-patent-case-fuels-us-court-test-of-stem-cell-right.html, archived at http://perma.cc/4FVE-4YC8; see also Miller, supra note 146, at 563 (discussing how academic and government researchers can use the stem cells for a small fee, and while they can publish their research or obtain patents on their discoveries, they must negotiate a licensing agreement with WARF in order to market a commercial product).

168. Burning Bridges, supra note 155.

169. Id.

170. $I d$.

171. Id.

172. Brief for the Appellee, Consumer Watchdog v. Wis. Alumni Research Found. (Fed. Cir. Aug. 14, 2013) No. 2013-1377.

173. Ben Butkus, Pfizer Licensing Deal with WARF Allows Firm to Develop hESC-based Therapies, Discovery Tools, GenOMEWeB (May 13, 2009), http://www.genomeweb.com/ biotechtransferweek/pfizer-licensing-deal-warf-allows-firm-develop-hesc-based-therapiesdiscovery-to, archived at http://perma.cc/5YGQ-TXNT.

174. Burning Bridges, supra note 155.

175. Id.

176. Bergman \& Graff, supra note 166 , at 419. 
beyond levels that can be supported by the value of single innovations." ${ }^{177}$ The problem with this thicket is that it creates too many hoops to jump though and slows the development of new technologies. ${ }^{178}$ This thicket especially affects the small industry players who cannot afford the licensing costs to the various patents needed to effectively conduct research. ${ }^{179}$

While WARF holds the two main patents to the stem cell lines and the methods of differentiation, different institutions have filed patents for other elements necessary for research. ${ }^{180}$ These include factors such as the specific culture conditions, growth factors, proteins, and hormones that are required in order to differentiate the stem cells. ${ }^{181}$ The patents on these items mean that there are few alternatives on the market. ${ }^{182}$ Therefore, licenses must be obtained not only for the stem cells themselves but also for all of the various biological elements needed for research. ${ }^{183}$ The various licenses greatly increase the cost of stem cell research and are likely to leave the field to large corporations willing to pay the high price. While some may argue that leaving the research and development of stem cell therapies to large pharmaceutical companies is best, it could lead to a situation similar to Myriad's BRACAnalysis where there are few treatment options on the market and consumers are faced with high out-of-pocket costs and little insurance coverage.

\section{The Future of Stem Cell Patenting After the Myriad Decision}

Since Myriad, legal scholars and members of the biotech industry have questioned how far Myriad's holding extends and whether or not it should cover the patenting of stem cells. ${ }^{184}$ On July 2, 2013, the group Consumer Watchdog filed an appeal in the Federal Circuit asking for all patents on human embryonic stem cells to be invalidated as products of nature in light of Myriad. ${ }^{185}$ Watchdog asserts that "the claimed stem cells are analogous to the isolated DNA segments in Myriad because their enumerated properties are inherent in all embryonic stem cells" 186 and "WARF did not create or alter the properties inherent in stem cells any more than Myriad created or altered the genetic information encoded in the

177. $I d$.

178. Id.

179. Id.

180. Id.

181. Id.

182. $I d$.

183. $I d$.

184. See generally Greely, supra note 131; Davis, supra note 131.

185. Maria Luisa Palmese \& Deborah A. Somerville, Consumer Watchdog v. WARF Stem Cell Case Could Test Myriad's Reach, KenYon \& KenYOn (Jul. 29, 2013), http://www.kenyon.com/ NewsEvents/Publications/2013/7-29-Consumer-Watchdog-v-WARF-Stem-Cell-Case-Could-TestMyriads-Reach.aspx, archived at http://perma.cc/Q5LX-DKCS.

186. Id. 
DNA it claimed." 187

According to Watchdog, WARF's United States Patent Number 7,029,913 claims the replication of the human embryonic stem cell in vitro. ${ }^{188}$ This in vitro human embryonic stem cell would have the same characteristics and chemical composition as natural embryonic stem cells. ${ }^{189}$ Therefore, WARF's patent is not related to a method or preparation or an application of the discovery, but rather "[identifies] properties that are inherent in all [embryonic stem] cells, including those that exist naturally." 190

Similarly, in Myriad, the patent was not for a method or a preparation of the BRCA DNA, but rather the BRCA DNA itself. ${ }^{191}$ WARF's patent on the culture of cells being "in vitro" is akin to Myriad "isolating" the BRCA DNA. ${ }^{192}$ "WARF did not create or alter the properties inherent in stem cells any more than Myriad created or altered the genetic information encoded in the DNA it claimed." 193

WARF, on the other hand, claims that because the human embryonic stem cells are grown in vitro and must be grown in a culture medium to survive, they are not the same as naturally occurring human embryonic stem cells and therefore are not a "product of nature." 194 WARF also bases its argument on the fact that the in vitro stem cells are superior to natural cells because they are able to "[proliferate] well past the stage where cells would normally die or differentiate" and have unique properties to them that are not present in natural cells. ${ }^{195}$

On March 4, 2014, the United States Patent and Trademark Office issued guidance to patent examiners in light of Myriad. ${ }^{196}$ This guidance outlines factors that patent examiners must take into consideration when determining patent eligibility for "claims reciting or involving laws of nature/natural principles, natural phenomena, [and] natural products." 197 The guidance could potentially play a key role in determining the validity of WARF's stem cell patents and seems to weigh against the patentability of stem cells.

The guidance makes clear that the holding of Myriad does extend beyond nucleic acids and DNA and that an item is only patentable if it is "significantly

187. Brief for the Appellant, at 2-3, Consumer Watchdog v. Wis. Alumni Research Found., (Fed. Cir. July 2, 2013) No. 2013-1377.

188. Id. at 9.

189. Id. at 15 .

190. Id.

191. Id.

192. $I d$.

193. Id.

194. Brief for the Appellee, at 36, Consumer Watchdog v. Wis. Alumni Research Found., (Fed. Cir. Aug. 14, 2013) No. 2013-1377.

195. Id. at 37.

196. Memorandum from Andrew H. Hirshfeld, Deputy Commissioner for Patent Examination Policy, to Patent Examining Corps. (Mar. 4, 2014), available at http://www.uspto.gov/patents/ law/exam/myriad-mayo_guidance.pdf, archived at http://perma.cc/J78K-DUR7.

197. Id. 
different" from the product in its natural state. ${ }^{198}$ Some of the factors weighing toward patentability include: the claim is something that appears to be natural, however it is different in structure and is not naturally occurring; the claim has elements that impose limits on the claim's scope so that others are not prevented from using the natural product; and the claim has elements that add to what is already well understood in the field of study. ${ }^{199}$ Some of the factors weighing against patentability include: the claim is something that is a natural product not significantly different in structure from what is found in nature; the claims are general and cover all practical application of the natural product; and the claim states elements that must be taken by others in order to use the natural product. ${ }^{200}$

In light of these factors issued by the USPTO, the Federal Circuit should seriously consider invalidating WARF's stem cell patents. The WARF patents are on stem cells that occur naturally in the human body, and while they may be modified to increase longevity, the fact that they can be used in the human body is an indication that they are not markedly different in structure than naturally occurring stem cells. Additionally, the WARF patents are so broad as to include all hESCs and their downstream products, essentially prohibiting anyone else in the field from using the cells in their natural state.

While it remains to be seen how the courts will come down on the patenting of stem cells as a product of nature, an invalidation of WARF's stem cell patents could have far reaching implications for the health care industry. As scientists inch closer to commercialized treatments using hES cells, a potential monopoly on the stem cell treatment industry is a real possibility. If the courts choose to invalidate the stem cell patents in light of Myriad, it could open up stem cell research and help to achieve key provisions of the ACA by developing treatment options that could lower the long term cost of chronic disease.

\section{Health Reform: What the Affordable Care Act Stands to Gain FROM THE INVALIDATION OF STEM CELL PATENTS}

At nearly eighteen percent, the United States spends a higher percentage of its Gross Domestic Product on health care than any other civilized nation. ${ }^{201}$ Health care costs in the United States are nearly twice as much as other developed countries. ${ }^{202}$ Much of this cost goes to the treatment of ongoing chronic diseases

198. Greg DeLassus, May, Myriad, and Multi-factor Balancing Tests, JDSUPRA (Mar. 7, 2014), http://www.jdsupra.com/legalnews/mayo-myriad-and-multi-factor-balancing02963/?utm_source=jds\&utm_medium=twitter\&utm_campaign=health, archived at http://perma.cc/5E4H-3E7H.

199. $I d$.

200. Id.

201. Jason Kane, Heath Costs: How the U.S. Compares with Other Countries, PBS NEWSHOUR (Oct. 22, 2012, 10:30 AM), http://www.pbs.org/newshour/rundown/2012/10/healthcosts-how-the-us-compares-with-other-countries.html, archived at $\mathrm{http} / / /$ perma.cc/XXB5-DUUT.

202. Id. 
such as diabetes and heart disease. ${ }^{203}$

A major initiative of the ACA is the mandated coverage for those with preexisting conditions. ${ }^{204}$ For many Americans with chronic conditions, their preexisting condition status prevented them from receiving health insurance prior to the ACA. As insurers will have to face the increased cost of insuring these individuals with ongoing chronic disease, stem cells offer the potential for a onetime treatment with an upfront cost as opposed to a lifetime of ongoing treatment. However, with licenses to the most promising stem cells being licensed to Geron Corporation, the invalidation of stem cell patents is an important step in opening up the research market to develop new therapies. ${ }^{205}$

\section{A. The Cost of Ongoing Treatment of Chronic Disease}

In the United States, nearly $\$ 0.75$ of every health care dollar goes to treat patients with a chronic disease. ${ }^{206}$ The amount of money spent on treating chronic illness in 2007 was "equivalent to paying 34 million salaries of \$50,000 each."207 "Chronic illness is a leading cause of premature death and disability in the United States with more than 133 million (45\%) of Americans being afflicted with at least one chronic condition." 208 Seven out of every ten Americans will ultimately die of a chronic condition. ${ }^{209}$

If the rate of chronic disorders in the United States continues to grow at the current rate, the cost will rise enormously by the year $2020 .^{210}$ For example, from 2010 to 2020 the cost of cancer is expected to increase $66 \%$, from $\$ 125$ billion to $\$ 207$ billion; Alzheimer's $40 \%$, from $\$ 172$ billion to $\$ 241$ billon; diabetes $58 \%$, from $\$ 194$ billion to $\$ 500$ billion; and cardiovascular disease $73 \%$, from $\$ 272$ billion to $\$ 470$ billion. ${ }^{211}$ In 2010, the United States spent $\$ 2.6$ trillion on health care costs alone. ${ }^{212}$ That is nearly $\$ 8233$ per person. ${ }^{213}$ As the prevalence of chronic conditions continues to rise over the next decade, Americans will continue to spend progressively more on health care treatment costs; this cost will

203. Aftab Hussain \& Patrick A. Rivers, The Economic Value of Investing in Regenerative Medicine, 36 No. 2 J. HEALTH CARE FIN. 45, 45 (2009).

204. David Nather, The Big Change: Covering Pre-Existing Conditions, Politico (Oct. 1, 2013), http://www.politico.com/story/2013/10/obamacare-guide-covering-pre-existing-conditions97457_Page2.html, archived at http://perma.cc/TE2J-UPTA.

205. Regalado \& Hamilton, supra note 159.

206. Hussain \& Rivers, supra note 203.

207. Id.

208. $I d$.

209. Id.

210. Id.

211. Chronic Disease in the United States, BIOTECHNOLOGY INDUS. ORG., http://www.bio.org/ articles/chronic-disease-united-states (last visited Oct. 9, 2013), archived at http://perma.cc/65KQK4FT.

212. Id.

213. Kane, supra note 201. 
be reflected in the increased insurance premiums resulting from the ACA mandate that no individual can be denied on the basis of a pre-existing condition. Some analysts suggest that without a way to better manage the treatment of chronic conditions, health care costs could rise to nearly $\$ 4.3$ trillion by $2020 .^{214}$

\section{B. Insuring Citizens with Pre-Existing Conditions}

One of the main pillars of the ACA is to provide insurance coverage for individuals who were previously denied on the basis of a pre-existing condition. ${ }^{215}$ Pre-existing conditions are those medical conditions that an individual had before he enrolled in a health insurance plan. ${ }^{216}$ Many preexisting conditions are chronic conditions such as asthma and heart disease. ${ }^{217}$ The ACA states:

A group health plan and a health insurance issuer offering group or individual health insurance coverage may not establish rules for eligibility (including continued eligibility) of any individual to enroll under the terms of the plan. . . based on any of the following health status-related factors: health status, medical condition (including both physical and mental illness), claims experience, receipt of health care, medical history, genetic information, evidence of insurability (including conditions arising out of acts of domestic violence), disability, any other health status-related factor determined appropriate by the Secretary. ${ }^{218}$

Where health insurers could previously deny coverage to adults with a preexisting chronic condition, the ACA mandates that these individuals be covered. The ACA pre-existing condition clause went into effect on January 1, 2014. ${ }^{219}$ At this point, the rest of the ACA was already in place, including the individual mandate. ${ }^{220}$ Because all Americans are required to have health insurance under the individual mandate, the cost of the chronic illness for those with a pre-existing condition is now being paid for by spreading the "cost of their illnesses . . . among a larger population of sick and healthy people." 221 This cost must be spread among the entire population because under the "community rating" provision of the ACA, "the health insurance company [cannot] charge [individuals] higher premiums if [they] have health problems." 222 The result is

214. Hussain \& Rivers, supra note 203.

215. Health Insurance Market Reforms: Pre-Existing Condition Exclusions, THE HENRY J. KAISER FAMILY FOUND., http://kaiserfamilyfoundation.files.wordpress.com/2013/01/8356.pdf(last visited Jan. 23, 2014), archived at http://perma.cc/Q9VM-ZMTD.

216. $I d$.

217. Id.

218. 42 U.S.C. § 300gg-4(a)(1-9) (2011).

219. Nather, supra note 204.

220. Id.

221. Id.

222. Id. at 2 . 
that while insurance coverage for those with chronic conditions may be lower, the overall premium cost for healthy Americans will increase to make up the difference. ${ }^{223}$ Therefore, finding a cure or potential detection method for chronic conditions is essential in order to reduce the cost of healthcare coverage across the board.

\section{Cost Effectiveness of Stem Cell Therapies}

Stem cell therapies offer this cost-effective treatment alternative. One example is the drug Apligraf, developed by the regenerative medicine company Organogensis. ${ }^{224}$ Organogenesis is one of the first companies to receive insurance reimbursement for stem cell treatment. ${ }^{225}$ The drug Apligraf, made with adult stem cells, is used to treat leg and foot ulcers related to diabetes. ${ }^{226}$ These wounds would cost up to $\$ 1000$ per week for a standard treatment. ${ }^{227}$ However, Apligraf costs $\$ 3200$ and essentially provides a cure for the condition, eliminating the need for weekly and reoccurring treatment. ${ }^{228}$ While drugs such as Apligraf have great treatment potential, the better treatment alternative would be to cure the diabetes itself. ${ }^{229}$ This is a cure that could potentially be achieved using human embryonic stem cells, however, this research is limited due to the WARF patents and Geron's licensing rights to pancreatic stem cell products. ${ }^{230}$

Some states have conducted research to analyze the potential economic benefits of stem cell therapies. One such study is the Michigan Prospect, published in 2008. ${ }^{231}$ The study looked at the top seven chronic diseases in the state of Michigan: Type 1 diabetes, Parkinson's disease, spinal cord injury, acute myocardial infarction, stroke, Alzheimer's disease, and Amyotrophic Lateral Sclerosis (ALS; Lou Gehrig's Disease). ${ }^{232}$ The study found that nearly 770,000 Michigan residents could benefit from stem cell therapy. ${ }^{233}$ The annual treatment costs for these conditions was $\$ 7.9$ billion. ${ }^{234}$ "It [was] projected that if stem cell therapy was utilized and only 1 percent of the benefits were realized, the state would save almost $\$ 80$ million in annual treatment costs and up to $\$ 2.3$ billion

223. Id.

224. Jill Sederstrom, Stem Cells: The Not Too Distant Future, Managed HealthCARE EXECUTIVE (Dec. 1, 2012), http://managedhealthcareexecutive.modernmedicine.com/managedhealthcare-executive/news/stem-cells-not-too-distant-future $\mathrm{id}=\&$ sk $=\&$ date $=\&$ page $\mathrm{ID}=4$, archived at http://perma.cc/QYH9-54FS.

225. Id.

226. $I d$.

227. Id.

228. Id.

229. Hussain \& Rivers, supra note 203, at 48.

230. Regalado \& Hamilton, supra note 159.

231. Hussain \& Rivers, supra note 203, at 48.

232. Id.

233. $I d$.

234. Id. 
over a 30-year period."235

The Michigan Prospect also looked at the effect of stem cell therapy on the state's Medicaid program. ${ }^{236}$ Michigan Medicaid had nearly 1.8 million members in $2004 .{ }^{237}$ If $0.5 \%$ savings (an extremely modest estimate) were to result from stem cell treatment therapy, the state would save almost $\$ 38.5$ million in a single year. ${ }^{238}$ This would mean nearly $\$ 255$ million in savings over a thirty-year period. ${ }^{239}$

Finally, the study analyzed the result in increased worker productivity as a result of stem cell treatment for chronic disease. ${ }^{240}$ The treatment of chronic disease would greatly improve the absentee rates for workers with a chronic condition. ${ }^{241}$ This would result in an annual savings of nearly $\$ 19.2$ million. ${ }^{242}$ Additionally, an increase in employment in the biotech industry from those researching and manufacturing these conditions would add about 800 new jobs to the state of Michigan. ${ }^{243}$

Michigan is not the only state to have looked at the effects of stem cell research on the state health programs. ${ }^{244}$ Proposition 71, the California Stem Cell Research Initiative, determined that stem cell treatment therapies had the potential to reduce health care spending for California residents by a reduction in insurance premiums and out-of-pocket costs. ${ }^{245}$ "If stem cell therapy reduce[d] insulin dependent diabetes by [fifty] percent, this alone would produce a savings of $\$ 122$ billion to California residents. ..."246

"[A]lthough an increase in savings would undoubtedly occur if stem cell therapy delivered on its promise to cure disease, savings would also occur if stem cell therapy reduced or even prolonged the symptoms of the disease," or delayed the onset of the condition or reduced the complications. ${ }^{247}$ While all of this evidence on the potential economic benefits of stem cell research is promising, invalidating the WARF patents is the first step. With the WARF patents in place, even if Geron were to develop a stem cell treatment for heart disease or diabetes, the result could be similar to the monopoly held by Myriad genetics over the BRCA gene. Geron would have a monopoly on the treatment and would limit the options in the marketplace, driving up costs.

235. Id.
236. Id.
237. Id.
238. Id.
239. Id.
240. Id.
241. Id.
242. Id.
243. Id.
244. Id. at 49.
245. Id.
246. Id.
247. Id.




\section{The Affordable Care ACt and Other Governmental Measures AS AN Alternative to Stem Cell PATENTS}

The invalidation of stem cell patents and their licenses could increase stem cell research and lead to a more rapid development of stem cell treatments in the United States. These treatments have the potential to cure many of America's most prevalent long-term diseases. In light of the ACA provisions requiring coverage for all Americans regardless of pre-existing conditions, Americans have much to gain from any reduction in treatment cost that would limit risk sharing among insureds. While patents are the primary incentive for researchers to continue with new research and development, there are other reward alternatives that still allow for competition in the marketplace. ${ }^{248}$ By invalidating stem cell patents and applying these alternatives, Americans can benefit from the reduced health insurance costs that will come with the required coverage for those with pre-existing conditions.

There are currently three primary ways of rewarding scientific innovation in the United States. ${ }^{249}$ These methods include governmental grants, tax credits, and patents. ${ }^{250}$ "The patent system imposes [research and development] costs primarily upon the consumers who purchase patented products."251 Grants and tax credits, on the other hand, "generally require all taxpayers to subsidize [research and development] regardless of whether they use the resulting products." ${ }^{252}$

When it comes to research and development in the healthcare industry, it makes sense for all taxpayers to subsidize the cost. ${ }^{253}$ In other areas of innovation, such as technology, the items that are developed and subsequently patented are often luxury items. ${ }^{254}$ The cost of these items is high and they are often purchased by the upper class. ${ }^{255}$ It makes sense that the individual consumer is paying for the research and development associated with the patent in these instances because few are using the product. ${ }^{256}$

However, with regard to healthcare, all individuals have the potential to develop a chronic disease over the course of their lifetime. Additionally, under the ACA, all individuals are helping to subsidize the cost of treating those with current and pre-existing chronic conditions. Therefore, by giving stem cell researchers a tax credit or grant as opposed to a patent, every individual in the

248. Daniel J. Hemel \& Lisa Larrimore Ouellete, Beyond the Patents-Prizes Debate, 92 TEX. L. REV. 303, 303 (2013).
249. Id.
250. Id.
251. Id.
252. Id.
253. Id.
254. Id.
255. $I d$.
256. Id. 
health care market subsidizes the cost. ${ }^{257}$ Everyone also reaps the benefit. The cost of all insurance premiums will decrease as a result and any given individual will have the benefit of a lower cost treatment should they ever be diagnosed with a chronic condition.

The government awards tens of billions of dollars in tax credits each year to encourage research and development. ${ }^{258}$ Tax credits also give researchers the advantage of having funding before making any novel discovery. ${ }^{259}$ In contrast, patents provide a reward only after a researcher discovers a new product. ${ }^{260}$ With the current stem cell patenting landscape and Geron holding the patent rights to some of the most important stem cell lines, biotech firms are unlikely to begin costly stem cell research with no guarantee they would be able to obtain a licensing agreement once they developed a marketable product. ${ }^{261}$ If a biotech company were to enter into a negotiation with Geron or WARF after the development of a commercial product, the biotech firm would be at a significant disadvantage. ${ }^{262}$ The firm would want to market the product in order to reap the benefits of the expensive research and development process, and therefore WARF and Geron would have the bargaining power to ask for "any royalty [they] desired, and the license seeker would have to relent." ${ }^{263}$ In contrast, the ex ante reward of tax credits means that small biotechnological firms have the ability to conduct research and compete with larger firms who have other sources of funding. ${ }^{264}$

When the Obama Administration wrote the ACA, they saw the potential in awarding small biotech firms a tax credit for research and development that could lead to breakthrough discoveries in health care treatment options. ${ }^{265}$ The original version of the ACA contains a research tax credit provision known as the "Qualifying Therapeutic Discovery Project."266 In this part of the Note, this author proposes that Congress extend the Qualifying Therapeutic Discovery Project to fund additional stem cell research and development in place of the current patent system.

\section{A. Proposal to Extend the Qualifying Therapeutic Discovery Project}

The Qualifying Therapeutic Discovery Project ("TPD") is a provision of the

257. $I d$. at 308 .

258. Id. at 303 .

259. Id. at 308 .

260. Id.

261. Miller, supra note 146, at 571.

262. Id.

263. Id.

264. Hemel and Ouellete, supra note 248, at 338.

265. See Philip H. Spector, The 50\% Tax Credit/Cash Grant for Life Sciences Companies, NAT'L REV. (Aug. 5, 2014), http://www.natlawreview.com/article/50-tax-credit-cash-grant-lifesciences-companies, archived at http://perma.cc/P3CU-KY79.

266. 26 U.S.C. $\S 48 \mathrm{D}(2010)$. 
ACA that awards tax credits or grants ${ }^{267}$ to

projects that show reasonable potential to result in new therapies, to treat areas of unmet medical need or to prevent, detect, or treat chronic or acute diseases and conditions, to reduce long-term health care costs in the United States, or to significantly advance the goal of curing cancer within a 30 year period. ${ }^{268}$

Enacted in 2010, Congress directed the program at small biotechnology firms (less than 250 employees) who had difficulties receiving funding from other sources. ${ }^{269}$ The credit covered up to fifty percent of a biotech firm's qualified investment, up to $\$ 5$ million. In 2010, the TPD resulted in almost 3000 biotech companies receiving a total $\$ 1$ billion dollars. ${ }^{270}$ In the state of Indiana alone, the federal government awarded thirty-five small biotech companies a tax credit or grant under the Qualifying Therapeutic Discovery Project. ${ }^{271}$ Indiana companies received a total of $\$ 10,293,530.56$ through the life of the program. ${ }^{272}$ At least three of the Indiana projects awarded grant money were directly involved in stem cell research. ${ }^{273}$

Congress did not renew the TPD after 2010. However, since 2010 a group of legislators has been trying to garner support for the renewal of the project. ${ }^{274}$ If the holding in Myriad is any indication, the patents on stem cells and their methods of derivation could be invalidated in the near future. This could eliminate the incentive of WARF and those with WARF licensing agreements to continue further research and development for fear that their findings will not be patent eligible. However, the TPD could provide some relief from this and allow small biotech firms to fill the stem cell research gap, leading to potentially groundbreaking discoveries to cure chronic disease.

The TPD, as part of the ACA, has the potential to take the place of some of the rewards provided by the patent system in an effort to help increase research

267. Companies could choose to receive the funding in the form of either a grant, or a tax credit. See Qualifying Therapeutic Discovery Projects Basic Information: Questions and Answers (July 7, 2010), http://www.irs.gov/uac/Qualifying-Therapeutic-Discovery-Projects-BasicInformation:-Questions-and-Answers, archived at http://perma.cc/WDV7-NQQM (discussing common questions about applying for a TPD grant).

268. Id.

269. Therapeutic Discovery Project Credit, BIOTECHNOLOGY InDUS. ORG., http://www.bio. org/category/therapeutic-discovery-project-credit (last visited Oct. 9, 2013), archived at http://perma.cc/B9EU-785W.

270. Id.

271. Qualifying Therapeutic Discovery Project Grants for the State of Indiana, INTERNAL REVENUE SERV., http://www.irs.gov/Businesses/Small-Businesses-\&-Self-Employed/QualifyingTherapeutic-Discovery-Project-Grants-for-the-State-of-Indiana (last visited March 8, 2014), archived at http://perma.cc/XJ7R-TETW.

272. Id.

273. Id. (listing all Indiana stem cell projects receiving grants).

274. H.R. 3473, 113th Cong. (2013). 
and development of treatments that could help to achieve other key provisions of the ACA. The TPD came on the heels of an executive order issued by President Obama in March, 2009. ${ }^{275}$ This order overturned a previous policy enacted under the Bush administration that limited federally funded stem cell research to only those stem cell lines created prior to August 9, 2011. ${ }^{276}$ President Obama authorized the National Institutes of Health to develop a policy for the federal funding of stem cell research and as a result this policy led to 195 available human embryonic stem cell lines for researchers, up from twenty under the Bush administration. ${ }^{277}$

When President Obama issued his executive order regarding stem cell research, he sent a clear message that his administration was dedicated to investigating the potential of stem cells to cure chronic diseases. ${ }^{278}$ The TPD further enhanced this goal by providing an incentive for small firms to invest in stem cell research and development. However, despite Obama's executive order opening up several stem cell lines for research, WARF's licensing policies for many stem cell lines still confine biotech firms who wish to continue research outside of an academic institution. ${ }^{279}$ The invalidation of patents would open up all stem cells lines for research without the need for high licensing costs. ${ }^{280}$ This research could lead to the development of treatments to cure chronic diseases and help achieve another key goal of the Obama Administration: affordable care for chronic diseases under the ACA.

\section{B. Why Patent Alternatives Will Not Mean the End of Stem Cell Research}

While the TPD would not have the same monetary implications as patents, such as the exclusive right to all profits from licensing, there are other incentives aside from patenting that would still encourage stem cell treatment development. ${ }^{281}$ For example, for researchers in academic institutions the primary goal of research is the incentive to publish, not the incentive to patent. ${ }^{282}$ Most stem cell researchers and other researchers in the life sciences field are academics

275. See generally Exec. Order No. 13,505, 74 Fed. Reg. 10,667 (Mar. 9, 2009).

276. EBSCO Publ'g, supra note 151.

277. Meredith Wadman, High Court Ensures Continued US Funding of Human EmbryonicStem-Cell Research, NATURE (Jan. 7, 2013), http://www.nature.com/news/high-court-ensurescontinued-us-funding-of-human-embryonic-stem-cell-research-1.12171, archived at http://perma.cc/B8T6-HGMN.

278. $I d$.

279. Jenny Shum, Moral Disharmony: Human Embryonic Stem Cell Patent Laws, Warf, and Public Policy, 33 B.C. INT'L \& COMP. L. REV. 153, 161 (2010).

280. See id. (commenting that WARF received intense criticism for the cost and restrictiveness of its licensing practices).

281. Leeron Morad, Note, Stemming the Tide: On the Patentability of Stem Cells and Differentiation Processes, 87 N.Y.U. L. REV. 551, 588-89 (2012).

282. Id. 
concerned with discovery and publication as opposed to patenting. ${ }^{283}$ Even without patent protection, these researchers are likely to continue their stem cell research in order to have publication rights. ${ }^{284}$

Also, for biotech firms and institutions concerned with funding sources, government grants provide an alternative to private investment. ${ }^{285}$ Government grants make up a majority of biotechnology research funding and this funding will continue to be available, even with the invalidation of the WARF patents. ${ }^{286}$

Additionally, large biotech firms still have the incentives to conduct research without patent protection with the hopes that they will be able to patent the particular treatment technique that results. ${ }^{287}$ Allowing for a biotech corporation to patent the treatment technique as opposed to the stem cells themselves would allow for research progress while still incentivizing investment in the final product. ${ }^{288}$ This would not prevent smaller biotech companies from also patenting treatment techniques, because eliminating the patents on the stem cells themselves would preclude a situation like that which resulted from Myriad's domination over the BRCA testing market. Other biotech firms were able to develop techniques for testing different from those which Myriad used; however, because Myriad had the patent on the genes themselves the other tests were considered patent infringement. ${ }^{289}$ Similarly, both small and large biotech firms could obtain patents on their stem cell treatment techniques, but no one company could hold a monopoly over all stem cell products.

A final reason that patent alternatives such as the continuation of the TDP will not mean the end of stem cell research is the length of biological patents. Patents are valid for a period of twenty years. ${ }^{290}$ Because the majority of WARF's stem cell patents were filed in 1995, they are set to expire in $2015 .^{291}$ While embryonic stem cell treatment will likely not be widespread by this point, "[m]ore important . . . are patents filed since [the original WARF patents] that address [the broad] techniques such as differentiation, stabilizing cell fate, and scaling up [procedures]. ${ }^{292}$ These patents have the potential to effect stem cell research and development for years to come and because of their breadth courts should invalidate them. When WARF's patent expires in 2015, the TDP can provide incentives for other smaller biotech firms to continue to invest in the research in hopes of finding a treatment for chronic disease.

283. Id.

284. Id.

285. Id.

286. $I d$.

287. Id.

288. Id.

289. Id. at 584 .

290. Alla Katsnelson, Stem Cell Patent Battle Continues, NATURE.Com (May 3, 2010), http://blogs.nature.com/news/2010/05/stem_cell_patent_battle_contin_1.html, archived at http://perma.cc/K2BX-MJPQ.

291. Id.

292. Id. 


\section{CONCLUSION}

If embryonic stem cell treatments follow in the footsteps of genetic testing for the BRCA1 and BRCA2 genes, patients diagnosed with serious chronic diseases could face high costs and limited options for stem cell treatments. With the United States currently undergoing major healthcare reform under the ACA, the need for accessibility to affordable treatment options for chronic diseases that cost patients and insurers billions of dollars each year is higher than ever.

Therefore, in light of Myriad, a court should invalidate the embryonic stem cell patents held by WARF because the hES cells, like genes, are products of nature. Because patents provide an incentive for researchers by ensuring funding and exclusivity, Congress should extend the Qualifying Therapeutic Discovery Project as an alternative to stem cell patents in order to provide funding to small biotech companies conducting stem cell research. These measures will ensure that the research for embryonic stem cell treatments continue, thereby offering affordable treatment options for patients with chronic conditions under the ACA. 
